\title{
Stabilizing Property of Expansive Soil with Different Sand Layers
}

\author{
K. Venkat Raman, P. Dayakar, R.Venkatakrishniah
}

\begin{abstract}
Sweeping Soil improves by better root development, water development, and furthermore by blending bits of the dirt profile, to give progressively uniform surface. As a ground improvement method to improve the quality of dangerous soils and this examination is done to comprehend the settlement conduct of layered soils. The dirt which is gathered was seen as risky in nature, which is all the more expanding in nature. The examples of soil are gathered from in and around Chennai. The sand utilized in this investigation is taken from close by site and is utilized to improve the hazardous soil by shaping a layer of required thickness. The primer tests are directed on the dirt examples to decide their properties according to IS models. After the fundamental test, the plate load tests are performed on the dirt with square plate $(10 \mathrm{~mm} \times 10 \mathrm{~mm})$ so as to know the bearing limit of soil. The heap tests are performed on sand and mud layers with fluctuating thickness of $5 \mathrm{~cm}, 10 \mathrm{~cm}$ and $15 \mathrm{~cm}$ of sand over mud soil. From the plate load test the heap settlement conduct of soil layers are examined. It very well may be reason that on the off chance that various layers of sands are given over Problematic soil, at that point It gets enough Load bearing obstruction which can be further gets actualized during Highways developments. The outcomes says that of $15 \mathrm{~cm}$ layer of sand shows most extreme burden bearing limit and indicated better burden - settlement diagrams also.
\end{abstract}

Keywords - Sweeping soil, Investigation,Settlement

\section{INTRODUCTION}

Load - settlement behaviour of supporting soil is an important data useful to assess the bearing capacity which is the function of various factors namely shapes and sizes. In this study the sand layer prepared in a model tank, which is made up of fiber sheets shows the Load-settlement behaviour by Load testing. Nagaraj, T.K. and Ullagaddi, P.P. has stated that by increasing the size of the footing will leads to the improvement of bearing capacity of the soil and in foundation[1]-[4]. As the size of the footing increases the bearing capacity and the load settlement behaviour of the soil improves. Gray and Michalowski and Zhao (1996) have concluded that the addition of polypropylene fibres significantly improved the behaviour of the soil by plate load test. From the outcomes it's seen that the settlement increments quickly and clarified through a joined impact of the persistent increment in the quality of the material

Revised Manuscript Received on October 22, 2019.

K. Venkat Raman, Department of Civil Engineering, Bharath Institute of Higher Education and Research, Chennai, India. Email: venkatraman.civil@bharathuniv.ac.in

P. Dayakar, Department of Civil Engineering, Bharath Institute of Higher Education and Research, Chennai , India. Email: dayakarpitti@yahoo.co.in

R.Venkatakrishniah, Department of Civil Engineering, Bharath Institute of Higher Education and Research, Chennai, India. Email: venkatapec@gmail.com everywhere disfigurements as saw in the triaxial tests, and the increments in the flat worries underneath the plate[5]-[6]. The outcomes inferred that there is an augmentation from 30 to 310 of the grating edge which is straightforwardly influenced by the polypropylene fiber and the heap force increments from around 23 to $122 \mathrm{kN} / \mathrm{m}^{2}$.

\section{METHODOLOGY}

\section{A. Clay Soil}

Soil is the blend of minerals, natural issues, gases, fluids and a bunch of smaller scale and large scale life forms that can bolster vegetation. Soil is a type of characteristic body that exists as a component of the pedosphere. In development soil assumes a significant job in choosing the sort of establishment to be laid and the bearing limit of the structure. Soil has a different trademark highlights, for example, growing, contracting, and so on. The dirts utilized in this examination are gathered from the close by site and the locally accessible sand is been utilized to a layer in the dirt stratum[7]-[10]. The dirt is chosen in the wake of looking at their physical and designing properties of them

\section{B. Plate Load Test}

The heap test is executed as appeared in figure 3 , the arrangement comprise of cell pressure unit which is associated with the information lumberjack and Liner Variable Displacement Transform (LVDT) which is likewise associated with the attachment at the back period of the information lumberjack[11]-[14]. An acrylic tank of $30 \mathrm{~cm} \mathrm{x}$ $30 \mathrm{~cm} \times 30 \mathrm{~cm}$ is set in the triaxial stacking outline and the heap is applied to the example through a plate size of $10 \mathrm{~cm} \mathrm{x}$ $10 \mathrm{~cm}$ place at focus, through load cell and the stacking outline. The stacking outline comprises of flexible rigging so the stacking and the emptying can be checked precisely.

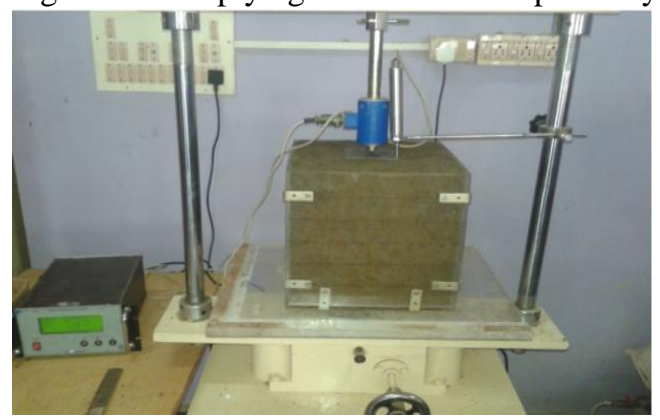

Figure 1: Plate Load test setup in Triaxial Loading Frame

The example which is put in the acrylic tank is set in the triaxial stacking outline and a steel plate is put at the focal point of the tanks as appeared in figure 2 .

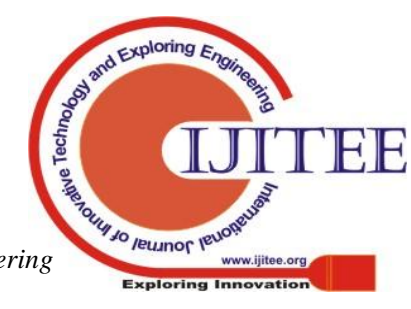


The plate of size $10 \mathrm{~cm} \times 10 \mathrm{~cm}$ is put at the middle and a steel ball is set at the focal point of the stacking test plate[15]-[18]. The heap cell is put to allow load over a circular steel ball. LVDT is utilized to decide the relocation of the plate which terms as the general uprooting of the acrylic tank as appeared in Figure 2.
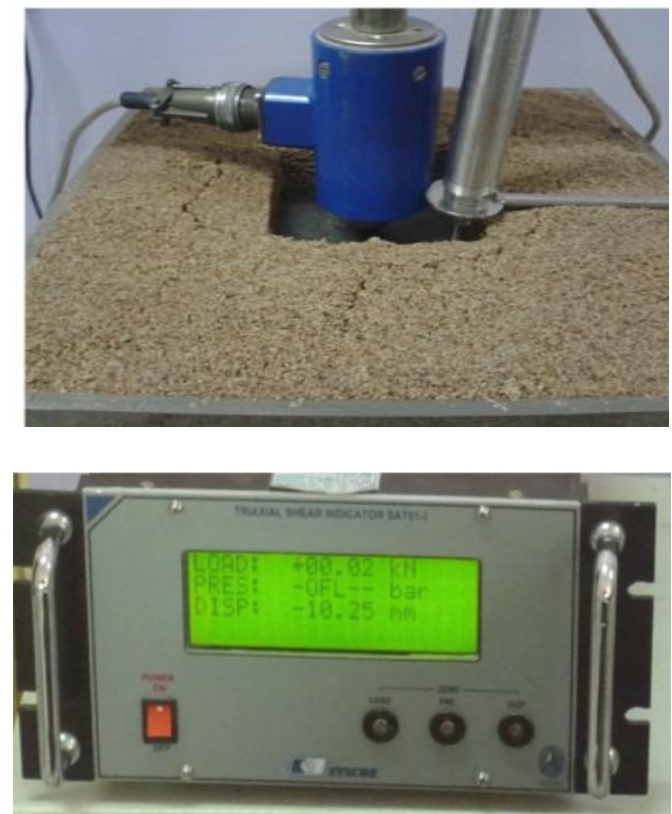

Figure - 2 Loading on Plate with Load Cell , Data Logger with Load and Displacement

\section{RESULTS AND DISCUSSIONS}

\section{A. Soil 1 (Clay)}

Index properties studied of the soil are summarized in Table 1. Index properties include (LL, PL, PI = LL-PL), specific gravity (Gs), Maximum dry density, Optimum moisture content All the other index properties of the natural soils are presented in Table 1.

\begin{tabular}{|c|c|c|c|c|c|c|c|}
\hline $\begin{array}{c}\text { Soil } \\
\text { Type }\end{array}$ & $\begin{array}{c}\text { LL } \\
(\%)\end{array}$ & $\begin{array}{c}\text { PL } \\
(\%)\end{array}$ & $\begin{array}{c}\text { PI } \\
(\%)\end{array}$ & Gs & $\begin{array}{c}\text { OMC } \\
(\%)\end{array}$ & $\begin{array}{c}\mathrm{MDD} \\
\mathrm{kN} / \mathrm{m}^{3}\end{array}$ & $\begin{array}{l}\mathrm{UCST} \\
\mathrm{kg} / \mathrm{m}^{2}\end{array}$ \\
\hline Clay & 76.85 & 21.36 & 52.30 & 2.63 & 25 & 1.39 & 3.96 \\
\hline
\end{tabular}

\section{B. Plasticity Index}

The plasticity index of a soil is the numerical difference between its liquid limit and its plastic limit. Both the liquid and plastic limits are moisture contents.

\section{Plasticity Index = Liquid Limit - Plastic Limit}

$\mathrm{PI}=\quad \mathrm{LL}-\mathrm{PL}$

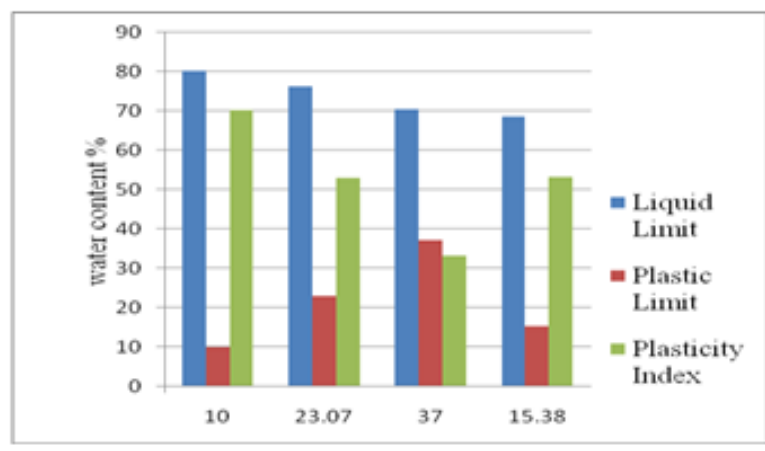

Figure - 3 Plasticity Index

\section{Compaction on clay}

In various constructions and other engineering structure loose soil are to be compacted to form a stable structure to improve their strength various measures are taken. Compaction is one of the effective and efficient methods which remove air voids in the soil by different source. The degree of compaction is measured in the form of dry unit weight[19]-[22].

The maximum dry density and optimum water contents are summarized in Table 1. Organic silt has the highest optimum water content $(25 \%)$ and its maximum dry density $1.39 \mathrm{~g} / \mathrm{cc}$.

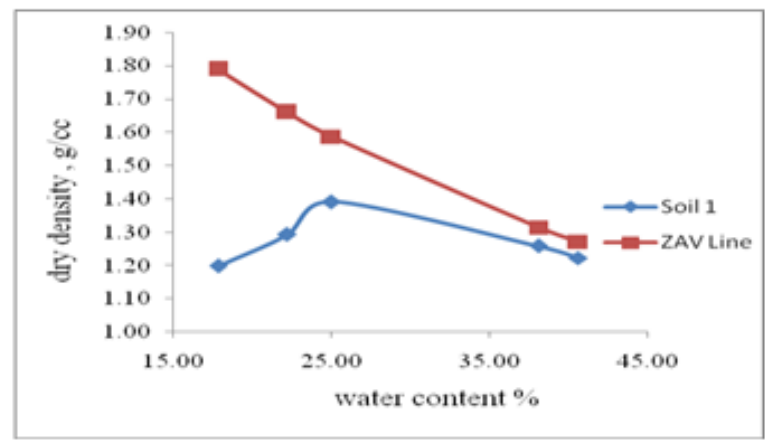

\section{B. Soil 2 (Sand)}

The other composite material used in this study is the sand which is highly variable the sand used in this study is locally available in the site. Sand is selected after examining their engineering properties[23]-[26]. From the grain size distribution it is examined that sand sample used in this study is poorly graded it is chosen to stabilize with the clayey soil. Index Properties of Sand

\begin{tabular}{ccccc}
\hline $\mathbf{G s}$ & OMC & MDD & $\mathbf{C c}$ & $\mathbf{C u}$ \\
$\mathbf{g} / \mathbf{c m}^{\mathbf{3}}$ & $\mathbf{( \% )}$ & $\mathbf{k N} / \mathbf{m}^{3}$ & & \\
& & & & \\
\hline $\mathbf{2 . 8 2}$ & 10 & 1.62 & 0.31 & 3.2 \\
\hline
\end{tabular}

$\mathrm{Gs}=$ Specific gravity

$\mathrm{MDD}=$ Maximum dry density

$\mathrm{OMC}=$ Optimum moisture content

$\mathrm{Cc}=$ Coefficient of Curvature

$\mathrm{Cu}=$ Coefficient of Uniformity 


\section{Compaction Test on Sand}

Sand compaction is a cost-effective method of ground improvement which is commonly used to improve soft seabed soils prior to land reclamation works. The maximum dry density and optimum water contents are summarized in Table 2.the highest optimum water content (10\%) and its maximum dry density $1.62 \mathrm{~g} / \mathrm{cc}$.

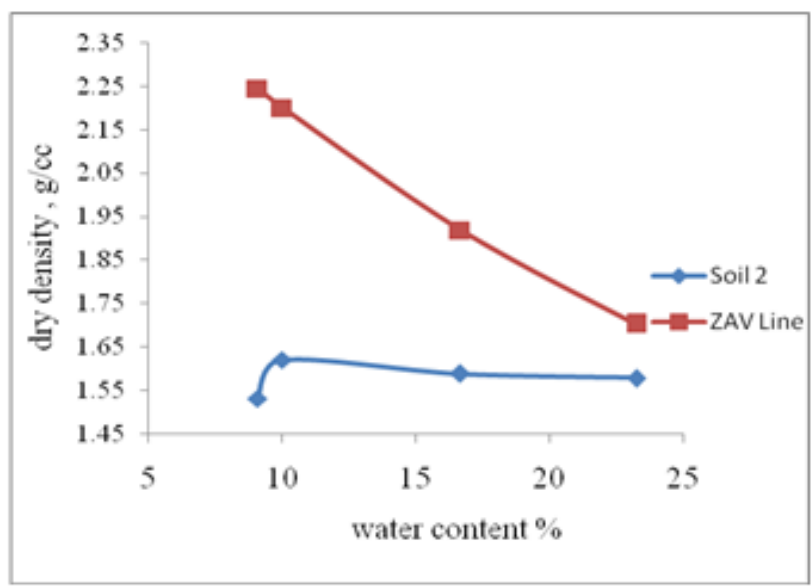

Figure - 5 Compactions curves of the studied Sand

\section{Sieve Analysis of sand}

The grain size analysis is widely used in classification of sand. The ratio of D60 to D10 is called coefficient of uniformity. $\mathrm{Cu}=\mathrm{D} 60 / \mathrm{D} 10=\mathrm{D} 10$ represents a particle size in $\mathrm{mm}$ such that $10 \%$ of the particles are finer than this size. D60 means $60 \%$ of the particles are finer than the size of the particle at $60 \%$ point on the curve[27]-[29]. The shape of the particle size indicated by coefficient of curvature $(\mathrm{Cc})=$ $(\mathrm{D} 30)^{2} /(\mathrm{D} 60 \mathrm{xD} 10)$. D30 - Particle size corresponding to $30 \%$ finer.

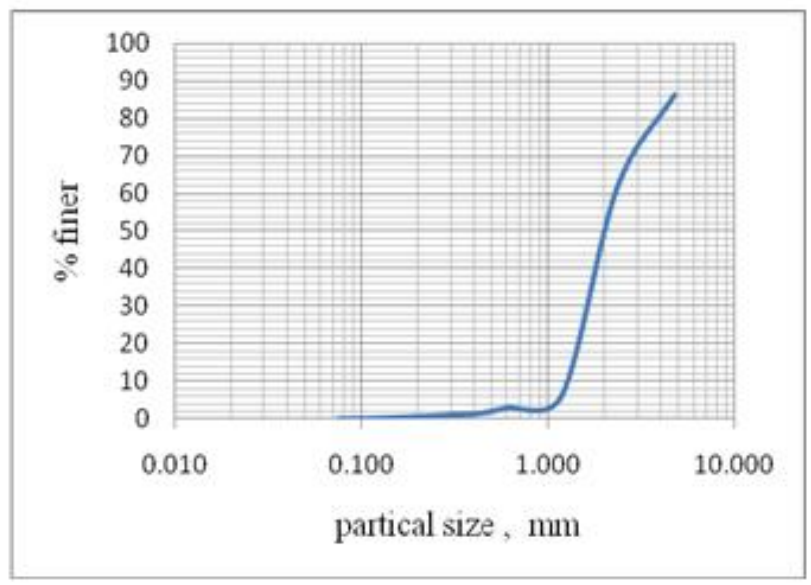

Figure -6 Sieve Analysis graph

\section{E. Plate load test on clay}

Layer's of different soil is done in an acrylic tank $(30 \mathrm{~cm} \mathrm{x}$ $30 \mathrm{~cm} \times 30 \mathrm{~cm}$ ) in room temperature of $28 \mathrm{C}$. The tank should be completely dry before filling the Clay. Water content should not be there. Once the tank should be filled with soil 1(clay) and again filled with soil 2(sand). Initially the tank gets fully filled with clay in compacted phase. Secondly the square plate of $10 \mathrm{~cm} \times 10 \mathrm{~cm}$ is placed over the compacted clay which is placed in the tank. Finally load is to be applied to find out the load- settlement behaviour of the soil. The maximum load obtained $325 \mathrm{kPa}$ at $5.95 \mathrm{~mm}$ displacement

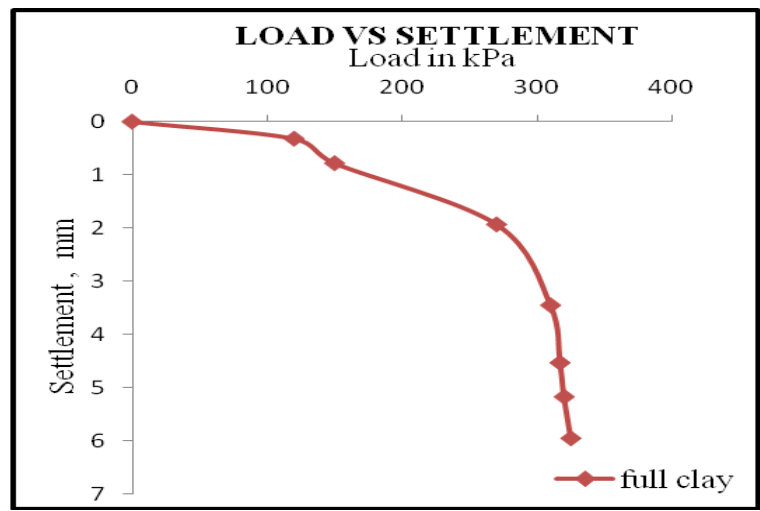

Figure - 7 Load vs Settlement curve of full clay

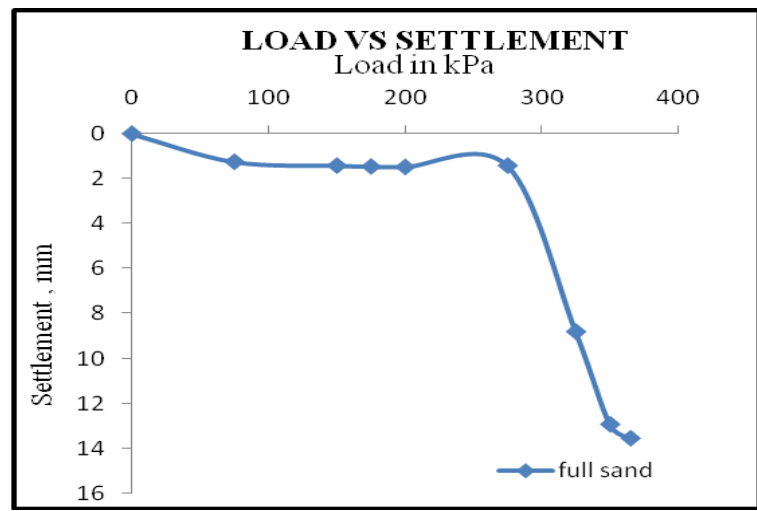

Figure -8 Load vs Settlement curve of full Sand

\section{F. Plate load test on fully sand}

Tank filled with fully soil 2(sand) having a square plate of $(10 \mathrm{~cm} \times 10 \mathrm{~cm})$ for plate load test, in order to find out the load- settlement behaviour of sand. The maximum load obtained $365 \mathrm{kPa}$ at $13.55 \mathrm{~mm}$ displacement.

\section{G. Plate load test on clay with $5 \mathrm{~cm}$ thick sand layer}

Tank filled with mostly soil 1(clay) i.e upto $25 \mathrm{~cm}$ layer and partially filled with $5 \mathrm{~cm}$ of thick layer with sand on the top having a square plate of $(10 \mathrm{~cm} \times 10 \mathrm{~cm})$ to perform the plate load test, in order to find out the settlement behaviour of problematic soil. The maximum load obtained $217 \mathrm{kPa}$ at $2.41 \mathrm{~mm}$ displacement.

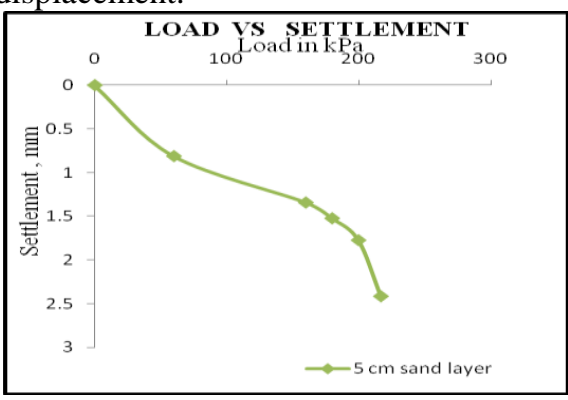

Figure - 9 Load vs Settlement curve of $5 \mathrm{~cm}$ thick

\section{Published By:}




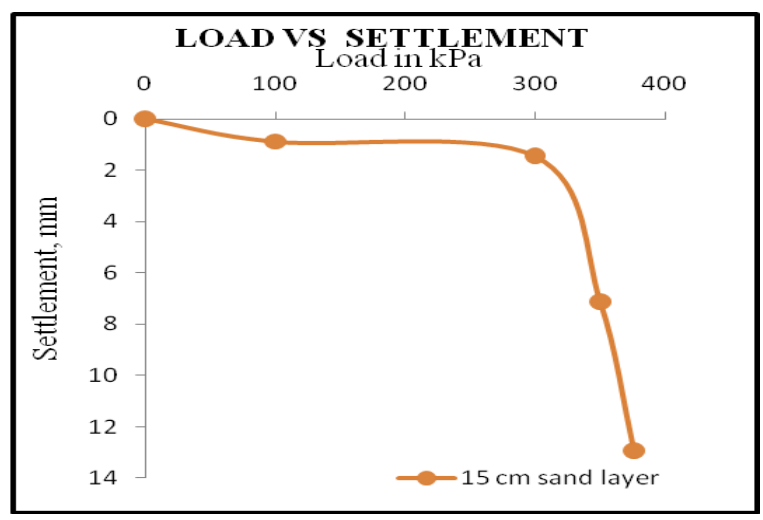

Figure - 10 Load vs Settlement, $15 \mathrm{~cm}$ sand layer

Tank filled with equally soil 1 (clay) i.e. upto $15 \mathrm{~cm}$ layer and in same quantity i.e $15 \mathrm{~cm}$ of thick layer of sand having a square plate of $(10 \mathrm{~cm} \times 10 \mathrm{~cm})$ to perform the plate load test, in order to find out the settlement behaviour of problematic soil. The maximum load obtained $376 \mathrm{kPa}$ at $12.93 \mathrm{~mm}$ displacement.

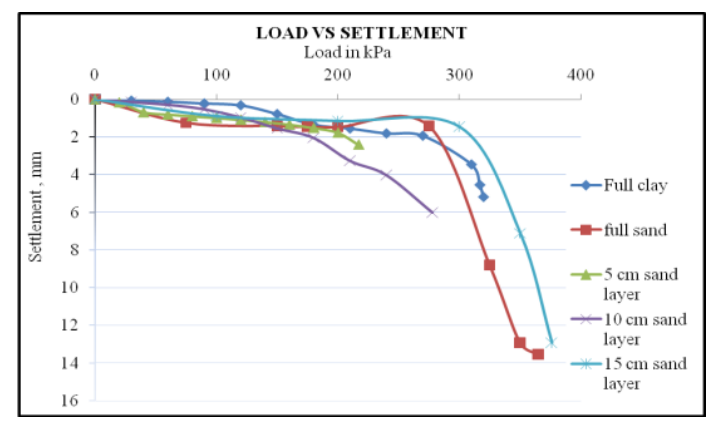

Figure11 - Load vs Settlement of sand layer

\section{H. Load Comparison of each layer at $\mathbf{2} \mathbf{~ m m}$ displacement}

Load intensity retains the maximum at $15 \mathrm{~cm}$ thick sand layer for $2 \mathrm{~mm}$ displacement

\begin{tabular}{|l|c|l|l|l|}
\hline \multicolumn{5}{|c|}{ Load Intensity kPa } \\
\hline Clay & Sand & $\begin{array}{l}\text { Sand layer } \\
\text { thickness (5 } \\
\text { cm) }\end{array}$ & $\begin{array}{l}\text { Sand layer } \\
\text { thickness } \\
(\mathbf{1 0} \mathbf{~ c m})\end{array}$ & $\begin{array}{l}\text { Sand layer } \\
\text { thickness } \\
(\mathbf{1 5} \mathbf{~ c m})\end{array}$ \\
\hline 271.84 & 278.92 & 206.1 & 180 & 304.77 \\
\hline
\end{tabular}

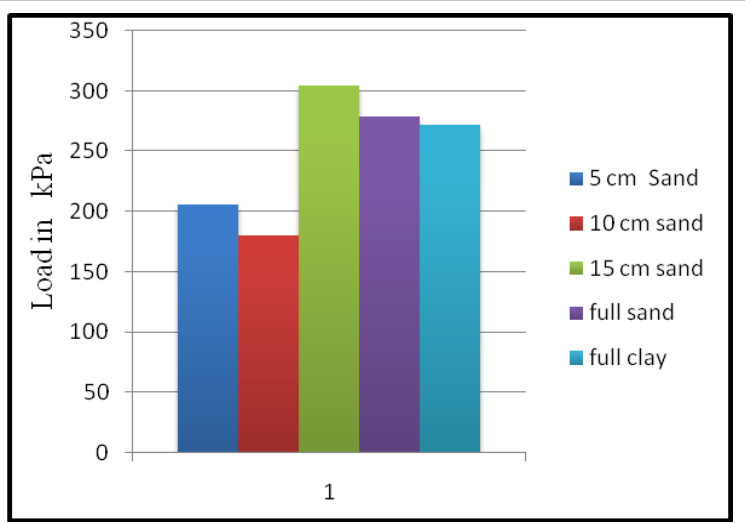

Figure 12 - Load Comparison at 2 mm displacement

I. Load Comparison of each layer at $2 \mathrm{~mm}$ displacement
Load intensity retains the maximum at $15 \mathrm{~cm}$ thick sand layer for $2 \mathrm{~mm}$ displacement.

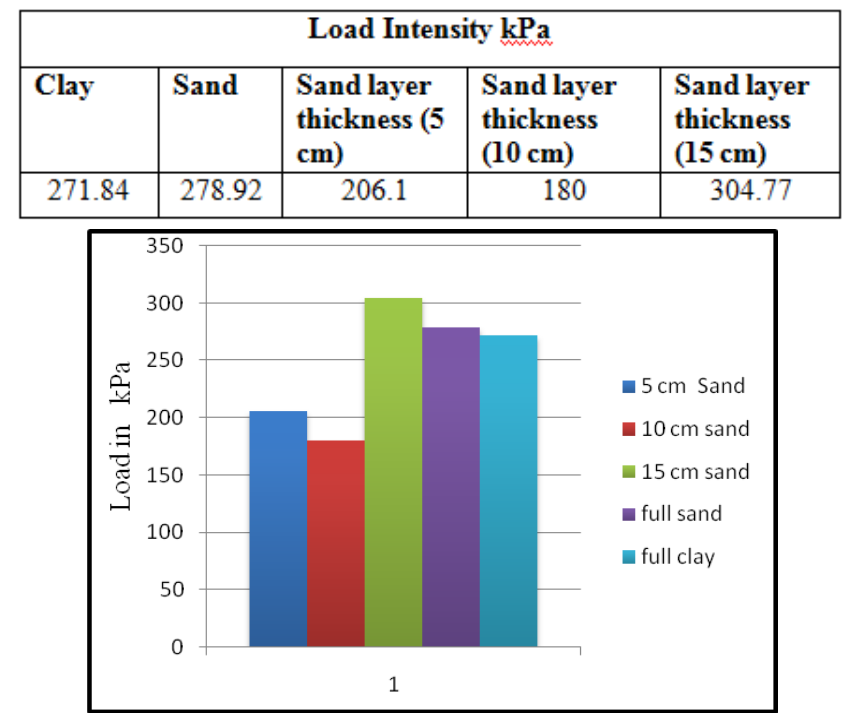

Figure - 13 Load Comparison at 2 mm displacement

\section{J. Load Intensity increase in percentage}

Following table and graphs shows percentage increment will be maximum at $15 \mathrm{~cm}$ thick sand layer for the same amount[30]-[31]. Load intensity remains the maximum at $15 \mathrm{~cm}$ thick sand layer which is $304.77 \mathrm{kpa}$, although it is tested for $5 \mathrm{~cm}$ thick layer, then for $10 \mathrm{~cm}$ thick layer for which we got the values as $206.1 \mathrm{kpa}$ and $180 \mathrm{kpa}$ respectively

\begin{tabular}{|c|c|c|c|c|c|}
\hline & Clay & Sand & $\begin{array}{l}\text { Sand } \\
\text { layer } \\
\text { thickne } \\
\text { ss (5 } \\
\text { cm) }\end{array}$ & $\begin{array}{l}\text { Sand } \\
\text { layer } \\
\text { thicknes } \\
\text { s (10 } \\
\text { cm) }\end{array}$ & $\begin{array}{l}\text { Sand } \\
\text { layer } \\
\text { thickness } \\
(\mathbf{1 5} \text { cm) }\end{array}$ \\
\hline Load Intensity & 271.84 & 278.2 & 206.1 & 180 & 304.77 \\
\hline Percentage \% & 16.36 & 23.58 & 24.18 & 33.78 & 45.90 \\
\hline
\end{tabular}

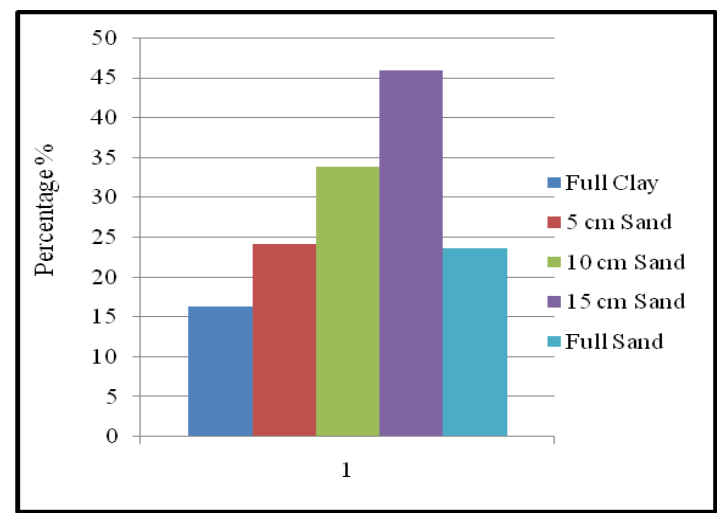

Figure - 17 Load Intensity increase in percentage

K. Load intensity Comparison with Ultimate Bearing Capacity

Ultimate Bearing capacity also retains to be maximum at 15 $\mathrm{cm}$ thick sand layer and for which its load intensity remains the most[32]-[34]. Ultimate Bearing Capacity also remains to be the most at $15 \mathrm{~cm}$ thick layer only and that is $320 \mathrm{kpa}$. In percentage terms also Load intensity remains the maximum and i.e percentage increase almost 3 times over entire clay. 


\begin{tabular}{|c|c|c|l|l|l|}
\hline & Clay & Sand & $\begin{array}{l}\text { Sand } \\
\text { layer } \\
\text { thick } \\
\text { ness } \\
\mathbf{5} \\
\mathbf{c m}\end{array}$ & $\begin{array}{l}\text { Sand } \\
\text { layer } \\
\text { thickne } \\
\text { ss (10 } \\
\mathbf{c m})\end{array}$ & $\begin{array}{l}\text { Sand } \\
\text { layer } \\
\text { thicknes } \\
\text { s (15 } \\
\mathbf{c m})\end{array}$ \\
\hline Load Intensity & 271.84 & 278.2 & 206.1 & 180 & 304.77 \\
\hline $\begin{array}{c}\text { Ultimate Bearing } \\
\text { Capacity }\end{array}$ & 308 & 285 & 191 & 205 & 320 \\
\hline
\end{tabular}

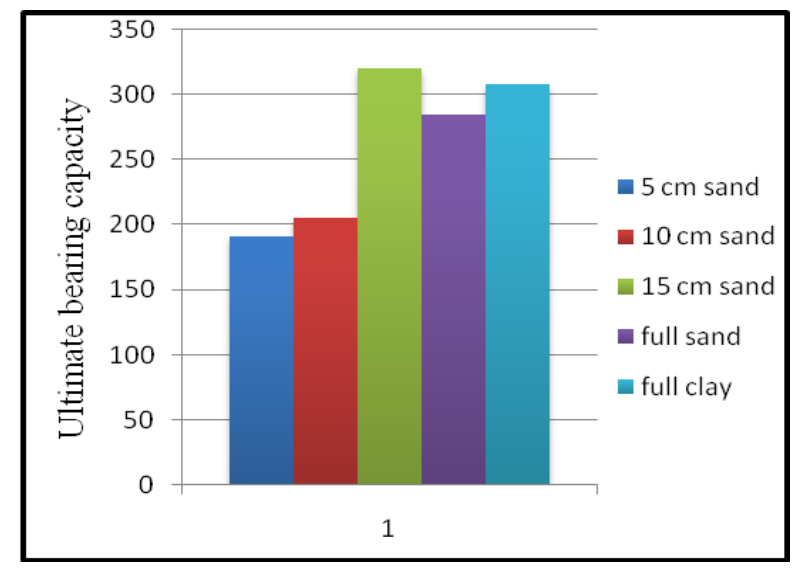

Figure 18 - Ultimate Bearing Capacity

\section{CONCLUSION}

Hence it can be concluded that regarding improvement in problematic soil is provided with the thickness of $15 \mathrm{~cm}$ of sand layer, the load caring capacity is greater comparatively. At $5 \mathrm{~cm}$ thick sand layer, much load bearing capacity have been noticed and with $10 \mathrm{~cm}$ thick sand layer then load bearing capacity got enhanced comparatively grater, again when the process carried further with $15 \mathrm{~cm}$ thick sand layer then it has reached the maximum bearing capacity and this being the half layer stage for both sand and clay as $30 \mathrm{~cm}$ tank is been taken. In this study it is justified that the process and methodology being carried out and finally it attains the maximum value for the load bearing capacity, with which when compared with the result i.e during $15 \mathrm{~cm}$ thick sand layer the load bearing capacity retains the maximum.

\section{REFERENCES}

1. Iyappan L., Dayakar P., Identification of landslide prone zone for coonoortalukusing spatial technology, International Journal of Applied Engineering Research,V-9,I-22,PP-5724-5732,Y-2014.

2. Kumar J., Sathish Kumar K., Dayakar P.,Effect of microsilica on high strength concrete, International Journal of Applied Engineering Research,V-9,I-22,PP-5427-5432,Y-2014.

3. Dayakar P., Vijay Ruthrapathi G., Prakesh J., Management of bio-medical waste, International Journal of Applied Engineering Research,V-9,I-22,PP-5518-5526,Y-2014.

4. Swaminathan N., Dayakar P., Resource optimization in construction project, International Journal of Applied Engineering Research,V-9,I-22,PP-5546-5551,Y-2014.

5. Venkat Raman K., Dayakar P., Raju K.V.B.,An experimental study on effect of cone diameters in penetration test on sandy soil, International Journal of Civil Engineering and Technology,V-8,I-8,PP-1581-1588,Y-2017.

6. Saritha B., Chockalingam M.P.,Photodradation of malachite green DYE using TIO2/activated carbon composite,International Journal of Civil Engineering and Technology,V-8,I-8,PP-156-163,Y-2017

7. Shendge R.B., Chockalingam M.P., Saritha B., Ambica A.,Swat modelling for sediment yield: A case study of Ujjani reservoir in Maharashtra, India,International Journal of Civil Engineering and Technology,V-9,I-1,PP-245-252,Y-2018
8. Chockalingam M.P., Balamurgan V.,Modernisation of an existing urban road-sector in Chennai, a case study report,International Journal of Civil Engineering and Technology,V-8,I-8,PP-1457-1467,Y-2017

9. Saritha B., Chockalingam M.P.,Adsorption study on removal of basic dye by modified coconut shell adsorbent, International Journal of Civil Engineering and Technology,V-8,I-8,PP-1370-1374,Y-2017

10. Saritha B., Chockalingam M.P.,Adsorptive removal of heavy metal chromium from aqueous medium using modified natural adsorbent,International Journal of Civil Engineering and Technology,V-8,I-8,PP-1382-1387,Y-2017

11. Chockalingam M.P., Palanivelraja S.,Retrospective analysis of a theoretical model used for forecasting future air quality near the north Chennai thermal power plant,International Journal of Civil Engineering and Technology,V-8,I-8,PP-1457-1467,Y-2017

12. Saritha B., Chockalingam M.P.,Photodegradation of methylene blue dye in aqueous medium by $\mathrm{Fe}-\mathrm{AC} / \mathrm{TiO} 2$ Composite,Nature Environment and Pollution Technology,V-17,I-4,PP-1259-1265,Y-2018

13. Shendge R.B., Chockalingam M.P., Kaviya B., Ambica A.,Estimates of potential evapotranspiration rates by three methods in upper Bhima Basin, In Maharashtra, India,International Journal of Civil Engineering and Technology,V-9,I-2,PP-475-480,Y-2018

14. Shendge R.B., Chockalingam M.P.,The soil and water assessment tool for Ujjani Reservoir,International Journal of Mechanical Engineering and Technology,V-9,I-2,PP-354-359,Y-2018

15. Shendge R.B., Chockalingam M.P.,A review on soil and water assessment tool,International Journal of Mechanical Engineering and Technology,V-9,I-2,PP-347-353,Y-2018

16. Sachithanandam P., Meikandaan T.P., Srividya T.,Steel framed multi storey residential building analysis and design,International Journal of Applied Engineering Research,V-9,I-22,PP-5527-5529,Y-2014

17. Meikandaan T.P., Ramachandra Murthy A.,Study of damaged RC beams repaired by bonding of CFRP laminates,International Journal of Civil Engineering and Technology,V-8,I-2,PP-470-486,Y-2017

18. Meikandaan T.P., Ramachandra Murthy A.,Retrofittng of reinforced concrete beams using GFRP overlays,International Journal of Civil Engineering and Technology,V-8,I-2,PP-423-439,Y-2017

19. Meikandaan T.P., Ramachandra Murthy A.,Flexural behaviour of RC beam wrapped with GFRP sheets,International Journal of Civil Engineering and Technology,V-8,I-2,PP-452-469,Y-2017

20. Meikandaan T.P., Murthy A.R.,Experimental study on strengthening of rc beams using glass Fiber,International Journal of Civil Engineering and Technology,V-9,I-11,PP-959-965,Y-2018

21. Meikandaan T.P., Hemapriya M.,Use of glass FRP sheets as external flexural reinforcement in RCC Beam,International Journal of Civil Engineering and Technology,V-8,I-8,PP-1485-1501,Y-2017

22. Saraswathy R., Saritha B.,Planning of integrated satellite township at Thirumazhisai,International Journal of Applied Engineering Research,V-9,I-22,PP-5558-5560,Y-2014

23. Saritha B., Ilayaraja K., Eqyaabal Z.,Geo textiles and geo synthetics for soil reinforcement,International Journal of Applied Engineering Research,V-9,I-22,PP-5533-5536,Y-2014

24. Ambica A., Saritha B., Changring G., Singh N B., Rajen M., Salman Md.,Analysis of groundwater quality in and around Tambaram taluk, Kancheepuram district,International Journal of Civil Engineering and Technology,V-8,I-8,PP-1362-1369,Y-2017

25. Arunya A., Sarayu K., Ramachandra Murthy A., Iye N.R.,Enhancement of durability properties of bioconcrete incorporated with nano silica,International Journal of Civil Engineering and Technology,V-8,I-8,PP-1388-1394,Y-2017

26. Ilayaraja K., Krishnamurthy R.R., Jayaprakash M., Velmurugan P.M., Muthuraj S.,Characterization of the 26 December 2004 tsunami deposits in Andaman Islands (Bay of Bengal, India),Environmental Earth Sciences,V-66,I-8,PP-2459-2476,Y-2012

27. Ilayaraja K.,Morphometric parameters of micro watershed in Paravanar sub-basin, Cuddalore District,International Journal of Civil Engineering and Technology,V-8,I-8,PP-1444-1449,Y-2017

28. Ilayaraja K., Singh R.K., Rana N., Chauhan R., Sutradhar N.,Site suitability assessment for residential areas in south Chennai region using remote sensing and GIS techniques,International Journal of Civil Engineering and Technology,V-8,I-8,PP-1468-1475,Y-2017 
29. Ilayaraja K., Reza W., Kumar V., Paul S., Chowdhary R.,Estimation of land surface temperature of Chennai metropolitan area using Landsat images,International Journal of Civil Engineering and Technology,V-8,I-8,PP-1450-1456,Y-2017

30. Chitra R.,Experimental study on beam using steel fiber and latex,International Journal of Civil Engineering and Technology,V-8,I-8,PP-1395-1403,Y-2017

31. Chitra R.,Analysis of traffic and management at Kovilambakkam intersection,International Journal of Civil Engineering and Technology,V-8,I-8,PP-1433-1443,Y-2017

32. Aswathy M.,Experimental study on light weight foamed concrete,International Journal of Civil Engineering and Technology,V-8,I-8,PP-1404-1412,Y-2017

33. Aswathy M.,Wastewater treatment using constructed wetland with water lettuce (Eichornia Crasipies),International Journal of Civil Engineering and Technology,V-8,I-8,PP-1413-1421,Y-2017

34. Kiruthiga K., Anandh K.S., Gunasekaran K, Assessment of influencing factors on improving effectiveness and productivity of construction engineers, 2015, International Journal of Applied Engineering Research, V - 10,I -17,p -13849-13854.

\section{AUTHORS PROFILE}

K. Venkat Raman Assistant Professor, Department of Civil Engineering, Bharath Institute of Higher Education and Research, Chennai, India.

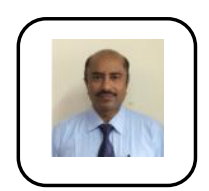

P . Dayakar Associate Professor, Department of Civil Engineering, Bharath Institute of Higher Education and Research, Chennai, India.

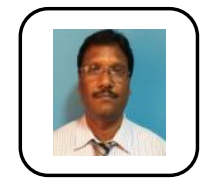

R.Venkatakrishniah Associate Professor, Department of Civil Engineering, Bharath Institute of Higher Education and Research, Chennai, India. 